\title{
DETERMINATION OF THE PARAMETERS OF MOTION OF THE GAS-LIQUID INTERFACE IN THE FUEL TANKS OF LAUNCH VEHICLE SPACE STAGES IN PASSIVE PORTIONS OF THE FLIGHT
}

\author{
Institute of Technical Mechanics \\ of the National Academy of Sciences of Ukraine and the State Space Agency of Ukraine \\ 15 Leshko-Popel St., Dnipro 49005, Ukraine; \\ e-mail: ${ }^{1}$ odnikolayev@gmail.com; ${ }^{2}$ ibloha@i.ua; ${ }^{3}$ khoryak@i.ua
}

To execute program motions, the space stages of liquid-propellant launch vehicles are equipped with restartable propulsion engines. On the shutdown of the propulsion engine of a space stage, the liquid propellant in the tank in microgravity conditions moves by inertia upwards as far as possible away from the intake. This results in the potential possibility of the pressurizing gas penetrating into the engine inlet in quantities that make an engine restart impossible. Because of this, motion parameter determination for a liquid moving in propellant tanks in microgravity conditions is a topical problem to be solved in the designing of liquid-propellant rocket engines. This paper presents a technique for the calculation of the parameters of motion of the gas-liquid interface in the propellant tanks of modern liquid-propellant launch vehicle space stages in microgravity conditions (between a start and a shutdown of their propulsion engines) taking into account the design features of in-tank propellant management devices. The technique is based on the use of the finite-element method, the volume-of-fluid method, and modern finite-element CAE systems. It allows one to determine the parameters of motion and the shape of the free liquid surface in the tank, the parameters of free gas inclusions formed in the liquid, and the efficiency of the in-tank propellant management devices in the passive portion of the launch vehicle flight for the normal operation of the propulsion system.

For the conditions of motion of a prototype propellant tank with a liquid in a drop tower, which simulates microgravity, the motion of a liquid in a cylindrical tank was simulated numerically accounting for the deformation of its free surface. The computed motion parameters of the liquid and the gas-liquid interface agree with the experimental data.

The technique developed will allow one to reduce the extent of testing of newly developed and upgraded launch vehicle space stages.

Keywords liquid-propellant rocket engine, propellant tank, in-tank propellant management devices, microgravitation, liquid free surface shape, parameters of gas inclusions in a liquid, drop tower, numerical simulation, finite-element method

1. Igdalov I. M., Kuchma L. D., Polyakov N. V., Sheptun Yu. D. Rocket as an Object of Control (in Russian). Dnepropetrovsk: ART-Press, 2004. 544 pp.

2. Shanov O. E., Degtyarev O. V., Pylypenko O. V., Zavoloka O. M., Nikolayev O. D., Sviridenko M. F. Ensuring operating efficiency of ilv space stages propellant feeding systems in different operating conditions IAC-15-D.2.3, 66th Astronautical Congress International. $7 \mathrm{pp}$.

3. Ducret E., Le Moullec L., Spencer B., Balaam P. Propellant management device studies, computational methods and neutral buoyancy tests. AIAA 28th Joint Propulsion Conference and Exhibit. 1992. Pp. 92-3611.

4. Kozlov A. A., Novikov V. N., Solovyev E. V. Feed and Control Systems of Liquid-Propellant Rocket Propulsion Systems (in Russian). Moscow: Mashinostroyeniye, 1988. 352 pp.

5. Pylypenko O. V., Zavoloka O. M., Nikolayev O. D., Sviridenko M. F. Workability of in-tank propellant management devices in the feed system of a launch vehicle space stage propulsion system (in Russian). Aerogasdynamics: Problems and Prospects (collected articles). 2006. Issue 2. Pp. 88-100.

6. Perfilyev L. A., Podobedov G. G., Sokolov B. A. Study of hydromechanics issues in zero gravity onboard the Mir orbital station (in Russian). Izvestiya RAN: Energetika. 2003. No, 4. Pp. 44-50.

7. Zhang-Guo LI, Qiu-Sheng LIU, Rong LIU, Wei HU, Xin-Yu DENG. Influence of Rayleigh-Taylor Instability on Liquid Propellant Reorientation in a Low-Gravity Environment. Chinese Physical Society and IOP Publishing Ltd. 2009. Vol.26, No.11. Pp.114701-1-114701-4.

8. Behruzi Ph., Michaelis M., Khimeche G. Behavior of the Cryogenic Propellant Tanks during the First Flight of the Ariane 5 ESC-A Upper Stage. 42nd AIAA/ASME/SAE/ASEE Joint Propulsion Conference \& Exhibit, Sacramento, California, AIAA 2006-5052. 9-12 July 2006. 10 pp.

9. Investigation of Propellant Sloshing and Zero Gravity Equilibrium for the Orion Service Module Propellant Tanks: final report / Microgravity University. Systems Engineering Educational Discovery. Kenosha. 2009. 22 pp. 10. Hirt C. W., Nichols B. D. Volume of fluid (VOF) method for the dynamics of free boundaries. Journal of Computational Physics. 1981. No. 39 (1). Pp. 201-225.

11. Kohnke P. Ansys Inc. Theory Manual. 001369. Twelfth Edition. Canonsburg : SAS IP, 2001. 1266 pp. 
12. Bussmann M., Mostaghimi J., Chandra S. On a three dimensional volume tracking model of droplet impact Phys. Fluids. 1999. 11(6). Pp. 46.

13. Brackbill J. U., Kothe D. B. , Zemach C. A Continuum Method for Modeling Surface Tension. Comput. Phys. 1992. Vol. 100. No. 2, June. Pp. 335-354.

14. Pozdnyshev N. O. Development the capillary devices of launch vehicle tanks and peculiarities of hydrodynamic processes simulation occurring in them. IAC-14-A2.2.3. URL: http://toc.proceedings.com/ 25520webtoc.pdf (last accessed on October 17, 2017).

15. Mikishev G. N., Churilov G. A. Effect of surface tension and wetting angle of liquid oscillation in vessels (in Russian). Spacecraft Dynamics and Space Exploration. Moscow: Mashinostroyeniye, 1986. Pp. 164-175.

16. Pylypenko O.V., Degtyarev A.V., Zavoloka O.M., Kashtanov A. E., Nikolayev O. D., Sviridenko N. F., Bashliy I.D. Determination of the parameters of gas-liquid structures formed in the propellant components during a start of the propulsion engine of a space stage with low tank filling levels (in Russian). Tekhnicheskaya Mekhanika. 2014. No. 4. Pp. 3-13.

17. Blokha I. D., Zavoloka O. M., Nikolayev O. D., Sviridenko N. F. Effect of the POGO vibration of a launch vehicle upper stage on the workability of in-tank propellant management devices in the propulsion engine feed system (in Russian). Tekhnicheskaya Mekhanika. 2005. No. 2. Pp. 65-74.

18. Davydov S. A. Calculation of the coefficient of penetration of a submerged liquid jet through a weaved netal net (in Russian). Aerospace Hardware System Design and Characteristic Analysis: collected articles. Dnipropetrovsk, 2004. Issue V. Pp. 13-21.

19. Sichevoy A. V., Davydov S. A., Gorelova K. V. Coefficient of dynamic loading of net-shaped propellant management devices (in Russian). Aerospace Hardware System Design and Characteristic Analysis: collected articles. Dnipropetrovsk, 2010. Issue .Pp. 106-113.

20. Hutchinson B. R., Raithby G. D. A Multigrid Method Based on the Additive Correction Strategy. Numerical Heat Transfer, 1986. $511 \mathrm{pp}$

21. Chorin A. J. Numerical solution of navier-stokes equations. Mathematics of Computation. 1968. Pp. 745762 .

22. Salzman J. A., Masica W. J., Lacovic R. F. Low-gravity reorientation in a scale-model Centaur liquidhydrogen tank (NASA TN D-7168, 1973). NASA official website - URL: https://ntrs.nasa.gov/ search.jsp?R=19730007525 (last accessed on October 17, 2017).

23. The Bremen Drop Tower. University Bremen official website. URL: https://www.zarm.uni-bremen.de/ en/drop-tower/team.html (last accessed on October 17, 2017). 